\title{
PENGARUH STRATEGI PEMBELAJARAN DAN KEMAMPUAN GERAK DASAR (MOTOR ABILITY) TERHADAP KEMAMPUAN SMASH SILANG PADA PERMAINAN SEPAK TAKRAW MAHASISWA PENJASKESREK FOK UNDIKSHA
}

\author{
I Ketut Semarayasa \\ Jurusan Penjaskesrek, Fakultas Olahraga dan Kesehatan \\ Universitas Pendidikan Ganesha \\ Singaraja, Indonesia \\ e-mail:semarayasaiketut@yahoo
}

\begin{abstract}
Abstrak
Permainan sepak takraw merupakan permainan tradisional yang memadukan dua permainan sepak bola dengan bola voli dipertandingkan di lapangan yang ukurannya menyerupai ukuran lapangan bulu tangkis permainan ganda. Permainan sepak takraw sudah menjadi permainan yang digemari baik dikalangan masyarakat umum dan pelajar Dalam bermain sepak takraw diperlukan beberapa teknik dasar. Salah satunnya adalah teknik dasar smash silang. Akan tetapi, mahasiswa Putra Jurusan Penjaskesrek FOK Undiksha dalam melakukan smash silang masih kurang maksimal. Sementara itu, untuk bisa menjadi seorang pemain sepak takraw yang baik, mereka juga harus memiliki tingkat kemampuan motorik yang tinggi. Penelitian ini dirancang untuk menginvestigasi pengaruh strategi pembelajaran dan kemampuan motorik terhadap keterampilan smash silang dalam permainan sepak takraw pada mahasiswa putra Jurusan Penjaskesrek FOK Undiksha.

Jenis penelitian ini adalah eksperimen lapangan, ini didasarkan pada variabel serta tujuan yang ingin dicapai dalam penelitian. Desain yang dipergunakan adalah faktorial $2 \times 2$. Dengan teknik pengambilan sampel menggunakan proporsional random sampling. Tes yang digunakan adalah Instrumen Barrow Motor Ability Test dan tes keterampilan dasar sepak takraw. Penelitian menyimpulkan: 1) Ada perbedaan antara strategi pembelajaran driil dan strategi bermain terhadap keterampilan smash silang dalam permainan sepak takraw, 2) Ada perbedaan keterampilan smash silang dalam permainan sepak takraw antara yang memiliki kemampuan motorik tinggi dan rendah, 3) Ada pengaruh interaksi antara strategi pembelajaran dan kemampuan motorik terhadap keterampilan smash dalam permainan sepak takraw.
\end{abstract}

Kata-kata kunci: drill, bermain, kemampuan gerak dasar, smash silang

\section{Abstract}

Games sepak takraw is a traditional game that combines two football games with a volleyball field measurements contested measure resembles badminton double game. Games sepak takraw is a well loved game from among the general 
public and students in playing sepak takraw needed some basic techniques. One is the basic technique smash scissors. However, students Physical Education, Health And Recreation Departement, Ganesha University Of Education in doing cross smash still less than the maximum. Meanwhile, to be able to become a good player takraw, they must also have a high level of motor skills as well. The study was then planned to investigate the influence of learning strategies and motor skill against skill cross smash in takraw game on student, students Physical Education, Health And Recreation, Ganesha Education Of University.

This type of research is experimental field, is based on variables and goals to be achieved in the study. Design used in this study is a $2 \times 2$ factorial. The sampling technique using proportional random sampling. Barrow Motor Ability Test instruments and test basic skills takraw. The study concluded: 1) There is a difference between learning strategies and strategy driil play against skill cross smash takraw game, 2) There are differences in skill cross smash takraw game between a high and low motor skills, 3) The influence of the interaction between learning strategies and motor skills of the game cross smash takraw skills.

Keywords: drill, play, basic motor skills, cross smash.

\section{PENDAHULUAN}

Smash adalah pukulan bola yang keras, tajam dan cepat melewati net yang diarahkan ke bidang lapangan lawan untuk mendapatkan poin atau nilai. Smash sepak takraw adalah salah satu teknik yang paling penting dan harus dikuasai oleh seorang pemain, karena dengan smash ini angka dapat dengan mudah diperoleh oleh regu yang bertanding dan dapat memenangkan suatu pertandingan dengan mudah.Melakukan smash melewati net dan masuk ke lapangan lawan merupakan salah satu tolok ukur keberhasilan dalam bermain sepak takraw. Ada beberapa cara melakukan smash, diantaranya adalah smash silang, smash lurus, smash telapak kaki dan smash silangyang perlu dipelajari dan dikuasai bila ingin menjadi pemain sepak takraw.

Sepak takraw adalah suatu permainan yang mempergunakan bola dari rotan atau plastic (synthetic fibre) dilakukan di atas lapangan empat persegi panjang, rata, baik terbuka maupun tertutup dan lapangan dibatasi oleh net. Sepak takraw adalah permainan sepak raga yang telah dimodifikasi untuk dijadikan sebuah permainan yang kompetitif. Permainan sepak takraw diselenggarakan di lapangan tertutup asalkan memenuhi syarat. Ukuran lapangan adalah $13,40 \mathrm{~m} \times 6,10 \mathrm{~m}$ bebas dari segala rintangan ke atas $8 \mathrm{~m}$ di ukur dari permukaan lantai dengan tinggi net 1,55 m (Maseleno dan Hasan: 2011). Permainan ini dimainkan oleh dua regu, masing-masing regu terdiri dari 3 orang dan setiap regu dilengkapi 1 orang cadangan dan satu tim terdiri dari 3 regu dan satu regu cadangan dan jumlah 1 tim tdak boleh lebih dari 12 orang. Menurut Sulaiman (2008) tujuan bermain sepak takraw dari setiap pihak adalah mengembalikan bola sedemikian rupa sehingga bola dapat jatuh di lapangan lawan atau menyebabkan lawan membuat pelanggaran atau pemain lawan membuat kesalahan. Sepak raga sebagai dasar permainan sepaktakraw adalah olahraga permainan tradisional Indonesia 
dimainkan oleh $6-7$ orang secara melingkar. Sepak takraw berasal dari dua kata yaitu sepak dan takraw. "Sepak" berarti gerakan menyepak sesuatu dengan kaki, dengan cara mengayunkan kaki di depan atau ke sisi. Sedangkan "Takraw" berarti bola atau barang bulat yang terbuat dari anyaman rotan. Permainan sepak takraw merupakan cabang olahraga beregu yang pelaksanaannya seperti pada bentuk permainan-permainan dengan menggunakan net, bola, serta lapangan dan juga peraturan-peraturan lainnya (Semarayasa, 2010: 66). Permainan sepak takraw menggunakan bagianbagian tubuh seperti: kepala, bahu, punggung, dada, paha, kaki, kecuali tangan. Secara sederhana maka permainan sepak takraw dapat dikatakan memiliki persamaan perpaduan antara sepakbola, bola voli, atau bulu tangkis. Menyerupai sepak bola karena dalam permainan sepak takraw dalam memainkan bola dengan menggunakan bagian-bagian tubuh seperti halnya dalam permainan sepak bola (yaitu; kaki, kepala atau bagian tubuh lainnya kecuali lengan). Menyerupai bola voli dan bulu tangkis karena sama-sama menggunakan net dan ukuran lapangan mendekati permainan bulutangkis. Dalam permainan sepak takraw peranan antropometrik dan profil fisiologis sangat menentukan dalam belajar sepak takraw (Jawis, et.al, 2006:11). Untuk dapat bermain sepak takraw yang baik dan benar, seorang dituntut untuk mempunyai kemampuan atau keterampilan yang baik. Kemampuan yang dimaksud adalah kemampuan dasar bermain sepak takraw, tanpa kemampuan seseorang tidak akan bisa bermain sepak takraw. Cara memainkan bola pada permainan sepak takraw yaitu; dengan menggunakan kaki, kepala, atau badan asalkan dalam keadaan memantul. Untuk dapat mengembalikan bola ke lapangan atau ke daerah lawan setiap regu diperkenankan menyentuh, menyepak atau menyundul bola tiga kali, baik itu dilakukan oleh ketiga pemain regu tersebut ataupun hanya salah satu anggotanya hal tersebut tidak jadi masalah, yang terpenting adalah setiap regu dalam permainan sepak takraw berhak menyentuh bola takraw sebanyak tiga kali menyepak atau memainkan bola dengan menggunakan bagian-bagian kaki, memainkan bola dengan kepala (main kepala), dengan dada, dengan paha, dengan bahu, (membahu), dan dengan telapak kaki dan bola harus sudah menuju ke lapangan lawan (Sulaiman, 2008:45).

Faktor teknik dalam permainan sepak takraw merupakan faktor penting yang harus diperhatikan, karena dengan memiliki teknik yang baik dan benar akan berdampak pada produktivitas dan efektivitas baik penyerangan maupun pertahanan dalam bermain sepak takraw. Adapun Keterampilan teknik dasar dalam pemainan sepak takraw, adalah; 1) servis, 2) passing, 3) heading, 4) smash, 5) block (PSTI, 2007 : 4). Melakukan smash dalam sepak takraw memiliki tingkat kerumitan dan kompleksitas yang berbeda-beda, dari keterampilan yang sederhana sampai pada keterampilan yang kompleks. Dipandang dari tingkat kesulitan dan kompleksitas, smash silang memiliki tingkat kesulitan dan kompleksitas yang tinggi karena mencakup unsur-unsur; koordinasi mata tangan dan kaki, timing, 
tempo, irama langkah, keseimbangan dinamis dan akurasi. Agar dapat melakukan smash silangyang baik perlu adanya pembelajaran kontinyu, progresivitas dan sistimatis. Dengan adanya suatu program dan juga pemilihan strategi pembelajaran yang sesuai dan tepat, niscaya tujuan pembelajaran akan tercapai karena strategi pembelajan yang tidak tepat tentu akan mengganggu pencapaian tujuan yang diinginkan. Mahasiswa Putra Jurusan Penjaskesrek FOK Undiksha dalam melakukan smash silang masih kurang maksimal dan belum bisa melakukan dengan baik. Padahal smash silang adalah teknik dasar yang sangat penting (mendasar) dalam permainan sepak takraw dan merupakan salah satu teknik dasar dalam permainan sepak takraw. Smash silang adalah salah satu teknik yang sangat penting (mendasar) dalam permainan sepak takraw yang memiliki kompleksitas gerakan yang cukup tinggi sehingga lebih sulit di pelajari oleh mahasiswa, lebih-lebih untuk mahasiswa yang belum terampil. Upaya meningkatkan kemampuan smash silangharus dilakukan dengan menerapkan strategi pembelajaran yang baik dan tepat. Karenanya perlu dirancang sebuah strategi pembelajaran yang tepat supaya mahasiswa mudah mempelajarinya, mengelola mahasiswa dan mengemas strategi pembelajaran yang bisa merangsang minat belajar mahasiswa sehingga mahasiswa tidak bosan dalam proses pembelajaran. Penentuan strategi pembelajaran yang tepat sangat berhubungan dengan situasi belajar sehingga harus memperhatikan dalam kondisi bagaimana dan di mana proses pembelajaran dilakukan. Disamping itu agar strategi pembelajaran yang akan diterapkan dapat terlaksana dengan baik, terlebih dahulu perlu ditelusuri faktor-faktor yang mempengaruhi keterampilan smash silang dalam permainan sepak takraw. Untuk dapat melakukan smash silang dengan baik diperlukan unsur-unsur kondisi seperti: daya tahan, kecepatan, kelentukan, ketepatan, keseimbangan, power dan koordinasi yang baik. Smash silang adalah pukulan smash yang dilakukan dengan menjulurkan kaki ke atas mengejar bola, dilakukan dengan putaran badan (tanpa salto) di udara (Sulaiman, 2008: 33). Smash silang dilakukan dengan memukul bola dengan kaki kanan ataupun kiri. Cara melakukan smash silang: Sikap awal berdiri membelakangi net, awalan harus dilakukan dengan cepat dengan cara melangkah atau lari kecil menuju arah datangnya bola,kemudian menolak ke atas dengan bertumpu pada salah satu kaki terlebih dahulu, kemudian segera diikuti dengan merendahkan badan dengan jalan menekuk lutut agak ke bawah, tolakan kaki tumpu ke atas secara eksplosif dengan bantuan lengan, luruskan tungkai serta putar badan (pinggul, punggung, bahu) ke arah dalam kemudian lakukan smash silang dengan putaran pinggul dan punggung. Gerakan ikutan dimulai dari tungkai, tungkai, punggung, bahu dan lengan secara bersamaan berputar ke arah luar, kemudian tungkai ditarik ke bawah dan mendarat dengan ke dua kaki. Kesalahan umum dalam melakukan smash silang meliputi: ketepatan antara datangnya bola dengan lompatan, penempatan bola tidak di atas bahu kiri atau kanan 
sementara pemain tidak memiliki fleksibilitas yang baik pada tungkai akibatnya smash bola bisa mengenai kepala sendiri, pemain terlambat mendaratkan kaki kiri terlebih dahulu kalau smsh dengan kaki kanan sehingga jatuh terduduk. Strategi metode drill merupakan cara mengajar yang baik untuk menanamkan kebiasaan-kebiasaan tertentu dan sekaligus sebagai sarana untuk memperoleh ketangkasan, ketepatan, kesempatan, dan keterampilan (Sagala, 2009: 217). Menurut Abdul Rahman Shaleh ( 2006: 203)," Ciri khas dari strategi ini (drill) adalah kegiatan yang berupa pengulangan yang berkali-kali supaya asosiasi stimulus dan respons menjadi sangat kuat dan tidak mudah untuk dilupakan. Dengan demikian terbentuklah sebuah keterampilan (pengetahuan) yang setiap saat siap untuk dipergunakan oleh yang bersangkutan". Strategi metode drill sangat sesuai apabila digunakan untuk siswa yang tujuan belajarnya adalah agar siswa menguasai ketrampilan gerak tertentuyang sudah pasti atau sudah baku dengan materi belajarnya berbentuk gerakan yang bersifat ketrampilan (Budiono, 2011:49). Dalam hal ini pembelajaran smash silang dilakukan dengan strategi konvensional yaitu, strategi pembelajaran dengan memilah-milah teknik gerakan smash silang. Artinya pembelajaran smash silang yaitu dengan melakukan gerakan teknik-teknik smash silang secara berulang-ulang. Berkaitan strategi metode drill Amung Ma'mum dan Toto Subroto (2001:7) menyatakan, strategi metode drill adalah cara belajar yang lebih menekankan komponenkomponen teknik. Simpulan yang diperoleh tentang strategi metode drill merupakan suatu cara mengajar dengan memberikan latihan-latihan terhadap apa yang telah dipelajari mahasiswa sehingga memperoleh suatu keterampilan tertentu. Strategi metode drill merupakan strategi metode pembelajaran yang menekankan pada penguasaan teknik suatu cabang olahraga yang dalam pelaksanaanya dilakukan secara Berulang-ulang. Dalam hal ini pembelajaran smash silang dengan strategi drill dilakukan drilling atau latihan secara terus menerus sesuai dengan apa yang diinstruksikan guru. Pengulangan gerakan ini dimaksudkan agar terjadi otomatisasi gerakan. Oleh karena itu, dalam strategi metode drill perlu disusun tata urutan pembelajaran yang baik agar siswa terlibat aktif, sehingga akan diperoleh hasil belajar yang optimal. Metode strategi drill menurut Syaiful Sagala (2010:217), merupakan suatu cara mengajar yang baik yang menanamkan kebiasaan tertentu, sarana untuk memperoleh suatu ketangkasan, ketepatan, kesempatan dan keterampilan. Metode strategi ini banyak di gunakan oleh guru-guru penjasorkes, karena di samping relatif mudah dalam pelaksanaannya juga manfaatnya sangat besar dalam proses pembelajaran cabang olahraga. Strategi bermain merupakan bentuk pembelajaran yang dikonsep dalam bentuk permainan (Budiono, 2011:48). Dalam pelaksanaan pembelajaran bermain menerapkan suatu teknik cabang olahraga ke dalam bentuk permainan. Melalui permainan, diharapkan akan meningkatkan motivasi dan minat mahasiswa untuk belajar menjadi lebih tinggi, sehingga akan 
diperoleh hasil belajar yang optimal. Strategi bermain merupakan bentuk pembelajaran yang dikonsep dalam bentuk permainan. Strategi bermain merupakan bentuk strategi strategi pembelajaran yang mengaplikasikan teknik ke dalam suatu permainan. Menurut Amung Ma'mum dan Toto Subroto (2001:2) bahwa, bermain sebenarnya merupakan dorongan dari dalam anak, atau naluri. Ciri lain yang sangat mendasar yakni kegiatan itu dilakukan secara sukarela, tanpa paksaan, dalam waktu luang. Berdasarkan karakteristik pada usia anak-anak tersebut, maka dalam membelajarkan suatu keterampilan olahraga disesuaikan dengan karakteristik perkembangannya.

Strategi bermain merupakan suatu strategi pembelajaran yang dikonsep dalam bentuk permainan. Dengan bermain anak akan mengekspresikan kegembiraannya dan berusaha menampilkan kemampuannya. Namun disisi lain seorang guru harus menanamkan sikap sportivitas, karena dalam bermain ada yang menang ada yang kalah. Seperti dikemukakan Rusli Lutan (1988:37) bahwa, karena permainan, akan menyebabkan adanya yang kalah dan yang menang, maka guru harus pula mengembangkan sikap seorang yang menang dan sikap seorang yang kalah secara fair kepada siswa, karena sikap seperti itu tidak terbentuk dengan sendirinya melalui permainan, maka usaha pengembangan sikap ini harus dilakukan secara terencana dan disengaja oleh guru. Dengan bermain hasrat gerak anak terpenuhi, namun di dalamnya terkandung unsur pembelajaran. Strategi permainan ini bertujuan untuk mengajarkan permainan agar anak memahami manfaat teknik permainan tertentu dengan cara mengenalkan situasi permainan tertentu terlebih dahulu kepada anak. Berdasarkan dua pendapat tersebut dapat disimpulkan bahwa, strategi bermain merupakan bentuk pembelajaran yang dirancang dalam bentuk permainan. Pembelajaran smash silang dengan strategi bermain yang dimaksudkan yaitu mempelajari smash silang yang dikonsep dalam bentuk permainan. Dalam hal ini guru telah merancang permainan smash silang. Bentuk permainan smash silang yaitu: melakukan smash yang diarahkan pada sasaran yang telah ditentukan. Dalam hal ini guru dapat menginstruksikan sasaran mana yang harus dikenai. Dalam pelaksanaannya dilakukan secara kompetisi antara mahasiswa yang satu dengan yang lainnya atau kelompok satu dengan kelompok lainnya. Barbara L.V dan Bonnie J.F (1996:44-45), memberikan contoh pembelajaran yang dilakukan secara kompetitif yaitu berteriak dan smash. Hal yang tidak kalah pentingnya yang juga sangat mempengaruhi tingkat keberhasilan dalam belajar gerak atau cabang olahraga pada umumnya dan smash silang sepak takraw pada khususnya adalah faktor mahasiswa itu sendiri. Setiap mahasiswa mempunyai kemampuan yang berbeda-beda dalam mempelajari suatu gerakan keterampilan. Perbedaan kemampuan terutama karena kualitas fisik. Kemampuan fisik berhubungan dengan kemampuan gerak dasar (motor ability) yang akan sangat mempengaruhi penampilan seseorang dalam belajar gerak dalam suatu cabang olahraga. 
Salah satu perbedaan dari setiap individu dalam mengembangkan suatu keterampilan gerak terletak pada kemampuan motorik atau kemampuan gerak dasar, terjemahan dari Motor Ability. Menurut James $\mathrm{R}$ Morrow et.al (2006: 327), bahwa kemampuan motorik merupakan suatu kapasitas umum yang berkaitan dengan prestasi dengan berbagai macam keterampilan atau lebih tepatnya dikatakan sebagai a general capacity of the individual that relates to the performance of skill or task. Kemampuan motorik adalah kapasitas dari seseorang yang berkaitan dengan pelaksanaan dan peragaan suatu keterampilan yang relative melekat (Nurhasan, 2000:20) Kemampaun motorik merupakan kualitas kemampuan seseorang yang dapat mempermudah dalam melakukan keterampilan gerak, oleh sebab itu kemampuan gerak dapat dipandang sebagai landasan keberhasilan masa yang akan datang didalam melakukan keterampilan gerak. Sedangkan menurut Sukintaka (2004:78) menjelaskan kemampuan motorik merupakan kualitas hasil gerak individu dalam melakukan gerak, baik gerakan non-olahraga maupun gerak dalam olahraga atau kematangan penampilan keterampilan motorik.

Kemampuan motorik merupakan faktor pendukung bagi pelaksanaan suatu keterampilan yang selanjutnya membedakan kemampuan individu, maka kemampuan motorik itu sendiri juga dapat dipahami semacam suatu faktor pembatas penampilan gerak seseorang. Sesorang yang mempunyai kemampuan motorik tinggi akan lebih efektif dalam melakukan semua jenis keterampilan olahraga. Kemampuan gerak dasar ini membawahi semua keterampilan gerak seseorang, jika seseorang dengan faktor gerak dasar tersebut besar maka kemungkinan akan sukses dalam setiap latihan atau gerak yang dipraktekkan.

Pengukuran kemampuan motorik secara teoritis akan memberikan gambaran mengenai kemampuan motorik yang mencakup berbagai jenis kegiatan fisik, oleh karena itu tes ini merupakan tes batre yang terdiri dari beberapa tes. Penelitian ini akan menggunakan tes Barrow Motor Ability Test yang terdiri dari beberapa butir tes yaitu: (1) standing broad jump, (2) soft ball throw, (3) zigzag run, (4) wall pass, (5) medicine ball put, (6) 60 yard dash (James Morrow et.al, 2005: 237).

Dari uraian di atas bahwa kemampuan motorik adalah kapasitas yang dimiliki seseorang yang terkait dengan penampilan gerak dan seseorang yang memiliki kemampuan motorik yang tinggi maka akan lebih baik dalam melakukan gerakan tersebut. Kemampuan motorik biasanya dianggap sebagai karakteristik yang relative stabil atau permanen, ditentukan faktor keturunan, dan berkembang relative secara otomatis dalam proses pertumbuhan, kematangan dan mereka tak mudah di ubah melalui latihan atau pengalaman. Dengan demikian dapat dikatakan bahwa kemampuan motorik yang baik adalah suatu syarat dalam usaha untuk mencapai prestasi yang maksimal bagi seseorang dalam belajar gerak smash silang dalam permainan sepak takraw. Perbedaan kemampuan motorik menjadi pertimbangan yang sangat penting dalam menentukan strategi pembelajaran yang sesuai dengan karakter dari seseorang 
sehingga bisa mencapai prestasi yang maksimal.

\section{METODE}

Penelitian ini dilaksanakan di Jurusan Penjaskesrek FOK Undiksha 2013. Penelitian dilaksanakan dengan frekuensi 3 kali seminggu dan 90 menit setiap kali pertemuan. Populasi adalah mahasiswa putra Jurusan Penjaskesrek pada tahun pelajaran $2013 / 2014$, terdiri dari empat kelas dan jumlah mahasiswa putra adalah 80 orang. Jenis penelitian adalah eksperimen lapangan, ini didasarkan pada variabel serta tujuan yang ingin dicapai dalam penelitian. Kerlinger (2002 : 645) menyatakan bahwa eksperimen lapangan adalah kajian dalam suatu nyata (realitas), dengan memanipulasi satu variabel bebas atau lebih dalam kondisi yang dikontrol dengan cermat oleh pembuat eksperimen sejauh yang dimungkinkan oleh situasinya. Sampel dalam penelitian sejumlah 40 orang. Teknik pengambilan sampel menggunakan proporsional random sampling yaitu suatu teknik pengambilan sampel secara acak dengan memberikan kesempatan yang sama dari masingmasing anggota populasi sebagai sampel, yang jumlahnya disesuaikan dengan jumlah anggota subyek yang ada dalam masing-masing kelompok (Suharsini Arikunto, 2003 : 126-128). Sejumlah mahasiswa yang memenuhi ketentuan terdapat 40 mahasiswa, selanjutnya diukur tingkat motorik-nya untuk mengetahui mahasiswa yang memiliki motorik tinggi dan rendah. Berdasarkan skor dari hasil pengukuran kemudian dihitung T-skornya dan selanjutnya di rangking. Berdasarkan sampel penelitian adalah 20 orang mahasiswa dengan skor tinggi dan 20 orang mahasiswa dengan skor rendah. Kemudian dari 20 orang mahasiswa yang terpilih dalam setiap taraf, ditetapkan secara undian ke dalam kedua kelompok strategi pembelajaran yaitu strategi drill dan bermain. Desain yang dipergunakan dalam penelitian ini adalah faktorial $2 \times 2$ (Sudjana, 2002 : 154). Penelitian ini melibatkan dua variabel bebas (independent) dan satu variabel terikat (dependent). Variabel bebas terdiri dari satu variabel manipulatif dan satu variabel atributif sedangkan variabel terikat dalam penelitian ini adalah keterampilan teknik dasar smash silangdalam permainan sepak takraw. Dalam pelaksanaan penelitian dan analisis data, seluruh data kemampuan motorik yang diperlukan dikumpulkan dengan pengukuran Barrow Motor Ability Test (James Morrow, 2006: 237). Sedangkan data keterampilan smash silang dalam permainan sepak takraw dikumpulkan dengan tes smash silang sepak takraw dari Sulaiman (2008 : 90). Data tentang kemampuan motorik diperoleh dengan menggunakan tes Barrow Motor Ability Test yang terdiri dari beberapa butir tes yaitu: (1) standing broad jump, (2) soft ball throw, (3) zigzag run, (4) wall pass, (5) medicine ball put, (6) 60 yard dash (James Morrow, 2006: 237). Tim peneliti terlebih dahulu menjelaskan aturan kepada siswa (testee) serta memberi contoh gerakan yang harus dilakukan sebelum tes dilaksanakan. Hal tersebut dimaksud untuk mempermudah pemahaman dan mencegah terjadinya kesalahan gerakan siswa (testee) melakukan serangkaian gerakan tes kemampuan motorik. Dari pengumpulan hasil tes tersebut, maka dapat 
ditentukan (1) testee yang memiliki kemampuan motorik tinggi, dan (2) testee yang memiliki kemampuan motorik rendah. Dasar untuk menentukan batas tinggi rendahnya kemampuan motorik adalah dari perhitungan rangking dari data yang terkumpul.

Data keterampilan smash silang sepak takraw dikumpulkan dengan tes keterampilan dasar sepak takraw (Sulaiman, 2008: 90).

\section{HASIL DAN PEMBAHASAN}

Objek dalam penelitian ini adalah perbedaan penguasaan keterampilan dasar smash silang dalam permainan sepak takraw sebagai hasil treatment antara penerapan strategi pembelajaran driil dan bermaindengan mempertimbangkan tingkat motor ability mahasiswa. Penelitian ini menggunakan rancangan factorial research dengan menggunakan anava dua jalur (Glass and Hopskins, 1984 : 272-301). Eksperimen faktorial adalah eksperimen yang hampir semua atau semua taraf pada sebuah faktor dikombinasikan atau disilangkan dengan semua taraf tiap faktor lainnya yang ada dalam eksperimen (Sudjana, 1989 : 148). Berdasarkan rasional tersebut, maka data dalam penelitian ini dapat dikelompokkan menjadi : (1) kelompok $A_{1}$ yaitu kelompok mahasiswa yang diajar dengan startegi drill, (2) kelompok $\mathrm{A}_{2}$ yaitu kelompok mahasiswa yang diajar dengan strategi bermain, (3) kelompok $\mathrm{B}_{1}$ yaitu kelompok mahasiswa yang memiliki tingkat motor ability tinggi, (4) kelompok $B_{2}$ yaitu kelompok mahasiswa yang memiliki tingkat motor ability rendah, (5) kelompok $A_{1} B_{1}$ yaitu kelompok mahasiswa yang memiliki tingkat motor ability tinggi yang diajar dengan stategi drill, (6) kelompok $A_{1} B_{2}$ yaitu kelompok mahasiswa yang memiliki tingkat motor ability rendah yang diajar dengan strategi drill, (7) kelompok $A_{2} B_{1}$ yaitu kelompok mahasiswa yang memiliki tingkat ability tinggi yang diajar dengan strategi bermain, dan (8) kelompok $A_{2} B_{2}$ yaitu kelompok mahasiswa yang memiliki tingkat motor ability rendah yang diajar dengan strategi bermain.

Tabel 1 Ringkasan anava 2x2

\begin{tabular}{|l|l|l|l|l|l|}
\hline $\begin{array}{l}\text { Sumber } \\
\text { Varians }\end{array}$ & \multicolumn{1}{|c|}{$\mathrm{dk}$} & \multicolumn{1}{|c|}{$\mathrm{RK}$} & \multicolumn{1}{|c|}{$\mathrm{F}_{\text {hitung }}$} & \multicolumn{1}{|c|}{$\mathrm{F}_{\text {tabel }}$} & \multicolumn{1}{c|}{ Ket } \\
\hline $\mathrm{A}$ & 1 & 11,025 & 5,536, & 4,11 & Signifikan \\
\hline $\mathrm{B}$ & 1 & 133,225 & 66,891 & 4,11 & Signifikan \\
\hline $\mathrm{AB}$ & 1 & 9,025 & 4,531 & 4,11 & Signifikan \\
\hline $\mathrm{D}$ & 36 & 1,617 & & & \\
\hline Total & 40 & & & & \\
\hline
\end{tabular}

Berdasarkan atas ringkasan tabel analisis varians dua jalur pada Tabel 1 tersebut, dapat ditarik beberapa simpulan sebagai berikut:

1. Untuk antar kolom, diperoleh harga $F_{(A) \text { hitung }}=5,536$, sedangkan harga $F_{\text {tabel }}$ pada $\mathrm{db}_{\mathrm{A}}=1$ dan $\mathrm{db}_{\mathrm{D}}=36$ untuk taraf signifikansi $5 \%=4,11$. Ini berarti bahwa $F_{\text {hitung }}$ lebih besar dari pada $F_{\text {tabel }}$ pada taraf signifikansi $5 \%\left(F_{h}=5,536>\right.$ $\left.F_{t(1 ; 36 ; 0,05)}=4,11\right)$. Dengan demikian, hipotesis nol $\left(\mathrm{H}_{0}\right)$ yang menyatakan secara keseluruhan tidak terdapat perbedaan penguasaan keterampilan 
dasar smash silang sepak takraw yang signifikan antara kelompok mahasiswa yang memperoleh pembelajaran strategi drill dan kelompok mahasiswa yang memperoleh pembelajaran strategi bermain, ditolak. Sebaliknya hipotesis alternatif $\left(\mathrm{H}_{1}\right)$ yang menyatakan bahwa terdapat perbedaan penguasaan keterampilan dasar smash silang dalam permainan sepak takraw yang signifikan antara kelompok mahasiswa yang memperoleh pembelajaran strategi drill dan kelompok mahasiswa yang memperoleh pembelajaran strategi bermain, diterima. Dengan demikian dapat disimpulkan bahwa secara keseluruhan terdapat perbedaan penguasaan keterampilan dasar smash silang dalam permainan sepak takraw yang signifikan antara kelompok mahasiswa yang memperoleh pembelajaran strategi drill dan kelompok mahasiswa yang memperoleh pembelajaran strategi bermain.

2. Untuk antar baris, diperoleh harga $_{\mathrm{F}(\mathrm{B}) \text { hitung }}=66,891$ dan harga Ftabel pada $d_{b B}=1$ dan $d_{b D}=36$ untuk taraf signifikansi 5\% sebesar 4,11. Hal ini berarti, bahwa harga Fhitung lebih besar dari pada harga Ftabel pada taraf signifikansi 5\% $(\mathrm{Fh}=66,891>\mathrm{Ft}(1 ; 36 ; 0,05)=$ 4,11 . Dengan demikian, hipotesis nol (н) yang menyatakan secara keseluruhan tidak terdapat perbedaan penguasaan keterampilan dasar smash silang dalam permainan sepak takraw yang signifikan antara kelompok mahasiswa yang memiliki tingkat motorik tinggi dan kelompok mahasiswa yang memiliki tingkat motorik rendah, ditolak. Sebaliknya hipotesis alternatif $\left.{ }_{\mathrm{H} 1}\right)_{\text {) yang menyatakan bahwa terdapat }}$ perbedaan penguasaan keterampilan dasar smash silang dalam permainan sepak takraw yang signifikan antara kelompok mahasiswa yang memiliki tingkat motorik tinggi dan kelompok mahasiswa yang memiliki tingkat motorik rendah, diterima. Dengan demikian dapat disimpulkan bahwa terdapat perbedaan penguasaan keterampilan dasar smash silang dalam permainan sepak takraw yang signifikan antara kelompok mahasiswa yang memiliki tingkat motorik tinggi dan kelompok mahasiswa yang memiliki tingkat motorik rendah. Dengan memperhatikan skor rata-rata yang diperoleh, kelompok mahasiswa yang memiliki tingkat motorik tinggi lebih baik dibandingkan dengan kelompok mahamahasiswa yang memiliki tingkat motorik rendah dalam penguasaan keterampilan dasar smash silang dalam permainan sepak takraw.

3. Untuk interaksi, harga $\mathrm{F}_{\mathrm{A} \times \mathrm{B} \text { (hitung) }}=4,531$ dan harga $F_{\text {tabel }}$ pada $\mathrm{db}_{\mathrm{AB}}=1$ dan $\mathrm{db}_{\mathrm{D}}=36$, untuk taraf signifikasi $5 \%$ sebesar 4,11 . Hal ini berarti nilai $F_{A \times B(\text { hitung) }}$ lebih besar dari pada nilai $F_{\text {tabel }}$ pada taraf signifikansi $5 \% \quad\left(F_{A \times B \text { hitung }}=4,531>F_{t(1 ; 36 ; 0,05)}=\right.$ 4,11). Dengan demikian, hipotesis nol $\left(\mathrm{H}_{0}\right)$ yang menyatakan tidak terdapat interaksi antara strategi pembelajaran dan tingkat motorik terhadap penguasaan keterampilan dasar smash silang dalam permainan sepak takraw, ditolak. Sebaliknya, hipotesis alternatif $\left(\mathrm{H}_{1}\right)$ yang menyatakan terdapat interaksi antara strategi pembelajaran dan tingkat motorik terhadap penguasaan keterampilan dasar smash silang bermain sepak takraw, diterima. Dengan demikian dapat disimpulkan bahwa terdapat interaksi antara strategi pembelajaran dan tingkat motorik terhadap penguasaan keterampilan 
dasar smash silang dalam permainan sepak takraw.

\section{PEMBAHASAN}

1. Perbedaan

Pembelajaran strategi drill dan strategi bermain Terhadap Keterampilan Teknik Dasar Smash Silang dalam Permainan Sepak Takraw

Berdasarkan pengujian hipotesis pertama ternyata ada perbedaan pengaruh yang signifikan antara kelompok mahasiswa yang mendapatkan strategi drill dan kelompok mahasiswa yang mendapatkategi bermain terhadap keterampilan teknik dasar smash silang dalam permainan sepak takraw Pada Mahasiswa Putra Jurusan Penjaskesrek FOK Undiksha. Apabila dilihat dari masing-masing nilai mean kelompok mahasiswa yang mendapatkan strategi bermain memiliki hasil yang lebih baik daripada kelompok mahasiswa yang mendapatkan strategi drill. $\mathrm{Hal}$ ini disebabkan karena penerapan strategi bermain dalam pembelajaran keterampilan teknik dasar smash silang dalam permainan sepak takraw sangat sesuai dengan karakteristik dari materi itu sendiri dan juga karakteristik perkembangan dari mahasiswa.

Karakteristik dari permainan sepak takraw (smash silang) adalah bentuk olahraga yang merupakan perpaduan dari beberapa jenis olahraga, seperti: senam, beladiri, sepakbola dan basket (Sulaiman, 2008 : 73). Cabang olahraga sepak takraw (smash silang) memerlukan berbagai komponen fisik terutama: kekuatan, kecepatan, kelenturan, keseimbangan, sehingga setiap pemain dituntut memiliki kondisi yang prima sehingga dapat menjalin sinergi gerak dengan pemain lainnya dalam satu regu sepak takraw. Karakteristik mahasiswa Penjaskesrek FOK Undiksha adalah masa dimana perubahan tubuh dan juga sistem fisiologis sangat mempengaruhi pencapaian kemampuan suatu gerak dan bisa menghadirkan suatu mekanisme dalam suatu proses penuaan (Gallahue dan Ozmun, 1988 : 411). Pada masa ini perubahan karena faktor pertumbuhan atau masa adolesensi yang mengalami perubahan yang sangat cepat. Pada masa ini terjadi peningkatan kemampuan yang dihasilkan atau disebabkan oleh proses pertumbuhan yang menyertai bertambahnya usia, dan juga dipengaruhi dari pengalaman dan latihan (Sugiyanto, 1998 : 210). Penererapan strategi bermain memberikan Pengertian yang mendalam (insight) kepada mahasiswa, mahasiswa dapat menikmati proses pembelajaran dengan senang dan tidak bosen, karena dalam proses pembelajaran ada unsur bermainnya.

Dalam pembelajaran yang menggunakan strategi bermain, proses pembelajaran keterampilan teknik dasar smash silang dalam permainan sepak takraw diajarkan variasi bermain dimana dalam melakukan smash silang melewati net dengan suatu sasaran yang ada skornya dan juga dengan teriakan. Keterampilan teknik dasar smash silang harus dipelajari secara bermain karena sepak takraw (smash silang) adalah salah satu cabang olahraga yang berbentuk permainan. 
2. Perbedaan Penguasaan Keterampilan Teknik Dasar Smash Silang dalam Permainan Sepak Takraw Antara yang Memiliki motorik Tinggi dan Rendah

\begin{abstract}
Berdasarkan pengujian hipotesis yang kedua ternyata terdapat perbedaan penguasaan keterampilan dasar smash silang dalam permainan sepak takraw yang signifikan pada mahasiswa putra Jurusan Penjaskesrek FOK Undiksha, di mana hasil penguasaan keterampilan teknik dasar smash silang dalam permainan sepak takraw kelompok mahasiswa yang memiliki tingkat motorik tinggi cenderung lebih baik dibanding dengan kelompok mahasiswa dengan motorik rendah.
\end{abstract}

Kemampuan

Motorik

Kemampuan motorik adalah kapasitas dari seseorang yang berkaitan dengan pelaksanaan dan peragaan suatu keterampilan yang relative melekat (Nurhasan, 2000:20) Kemampaun motorik merupakan kualitas kemampuan seseorang yang dapat mempermudah dalam melakukan keterampilan gerak, oleh sebab itu kemampuan gerak dapat dipandang sebagai landasan keberhasilan masa yang akan datang didalam melakukan keterampilan gerak.

Sehingga apabila seseorang memiliki tingkat motorik yang tinggi maka dapat dengan mudah dalam melakukan keterampilan gerak daripada mahasiswa yang memiliki motorik rendah, oleh sebab itu kemampuan gerak dapat dipandang sebagai landasan keberhasilan masa yang akan datang didalam melakukan keterampilan gerak.

\section{Interaksi Antara Strategi Pembelajaran dan Kemampuan Gerak Dasar (Motor Ability) Terhadap Penguasaan Keterampilan Dasar Smash silang Sepak Takraw}

Dari hasil analisis data tentang interaksi antara Strategi Pembelajaran dan Kemampuan motorik terhadap penguasaan keterampilan dasar smash silang sepak takraw mahasiswa putra Jurusan Penjaskesrek FOK Undiksha, dapat disimpulkan bahwa terdapat interaksi antara strategi pembelajaran dan kemampuan motorik terhadap penguasaan keterampilan dasar smash silang dalam permainan sepak takraw. Pada kelompok mahasiswa yang memiliki kemampuan motorik tinggi, penguasaan keterampilan dasar smash silang dalam permainan sepak takraw kelompok mahasiswa yang mengikuti pembelajaran dengan strategi bermain lebih baik dibandingkan kelompok mahasiswa yang mengikuti pembelajaran dengan strategi drill. Sedangkan pada kelompok mahasiswa yang memiliki motorik rendah, penguasaan keterampilan dasar bermain sepak takraw kelompok mahasiswa yang mengikuti pembelajaran dengan strategi drill lebih baik dibandingkan kelompok mahasiswa yang mengikuti pembelajaran dengan strategi bermain.

\section{KESIMPULAN}

Berdasarkan hasil penelitian dan pembahasan, maka dalam penelitian ini dapat diperoleh kesimpulan sebagai berikut :

1. Ada perbedaan pengaruh yang signifikan antara menggunakan strategi drill dan bermain terhadap keterampilan dasar smash silang dalam 
permainan sepak takraw mahasiswa Penjaskesrek FOK Undiksha tahun pelajaran2013/2014, di mana secara keseluruhan strategi bermain lebih baik dari strategi drill.

2. Ada perbedaan kemampuan dasar smash silang dalam permainan sepak takraw antara yang memiliki tingkat kemampuan motorik tinggi dan rendah pada mahasiswa Penjaskesrek FOK Undiksha tahun pelajaran 2013/2014, dimana kelompok mahasiswa yang memiliki tingkat kemampuan motorik tinggi lebih baik dibandingkan dengan kelompok mahasiswa yang memiliki tingkat kemampuan motorik rendah.

3. Terdapat pengaruh interaksi antara strategi drill dan bermain terhadap keterampilan dasar smash silang dalam permainan sepak takraw mahasiswa Penjaskesrek FOK Undiksha tahun pelajaran2013/2014.

\section{SARAN}

Terkait dengan hasil simpulan dalam penelitian ini, maka ada beberapa hal yang disarankan sebagai berikut :

1. Kepada guru penjasorkes ataupun pelatih, dalam memilih dan menggunakan pembelajaran memperhatikan strategi peserta didik. sebaiknya karakteristik

2. Kepada para guru penjasorkes, dalam belajar smash silang dalam permainan sepak takraw dapat menggunakan strategi bermain dan drill, yang disesuaikan dengan tingkat kemampuan motorik mahasiswa.

\section{DAFTAR PUSTAKA}

Amung Am'un dan Toto Subroto. 2001. Strateg Keterampilan Taktis dalam Permainan Bola Voli. Jakarta: Ditjen Olahraga.

Bompa. 2000. Total Training for Young Champion. Champign: Human Kinetics.

Budiono, Kodrat. 2011. Pengaruh Strategi Pembelajaran dan Kemampuan Gerak terhadap hasil belajar Sepak dan Tahan Bola dalam Permainan Sepak Bola. Jurnal ISSN; 1411-8319 Vol. 11 No 3 Tahun 2011. Tersedia Pada http://ejournal.utp.ac.id/index.php/ JIS/article/view/37 [Diakses tanggal 27 Agustus 2012].

Herywansyah. 2011. Perbedaan Pengaruh Strategi Pembelajaran dan Persepsi Kinestetik Terhadap Hasil Tembakan Lay Up Bolabasket. Jurnal ISSN; 14118319 Vol. 11 No 3 Tahun 2011. Tersedia Pada http://ejournal.utp.ac.id/index.php/ JIS/article/view/37_[Diakses tanggal 23 Agustus 2012].

Maseleno A dan Hasan M. 2011. Fuzzy Logic Based Analysis of the Sepak takraw Games Ball Kicking with the Respect of Player Arrangement. World Applied Programming, Vol (2), Issue (5), May 2012. 285-293 Special section for proceeding of International E-Conference on Information Technology and Applications (IECITA) 2012. ISSN: 2222-2510 C2011 WAP journal. Tersedia pada. www. waprogramming.com. [Diakses tanggal 27 Agustus 2012]

Jurnal Pendidikan Indonesia | 384 
Kerlinger, Fred N. 2002. Asas-asas Penelitian Behavioral (Edisi terjemahan oleh $\mathrm{R}$ Simatupang). Bandung: Gajah Mada University Pres.

Magill, Richard A. $2001 . \quad$ Motor Learning: Consepts and Applications $6^{\text {th }}$ ed. New York: Mc. Graw-Hill Companies.

Morrow JR dkk. 2006. Measurement And Evaluation in Human Performance. Kanada: Human Kinetics.

Nurhasan. 2000. Tes dan penggukuran pendidikan olahraga. Jakarta: FPOK UPI

Pate, Russell R., Cleneghan, Bruce Mc and Rottela, Robert. 1984. Scientific Foundations of Coaching. New York: Sounders Colege Publishing.

PB PSTI. 2007. Peraturan Permainan Peraturan Perwasitan dan Peraturan pertandingan Sepak Takraw. Jakarta: PB PSTI.

Rusli Lutan. 1988. Belajar Keterampilan motorik: Pengantar Teori dan Metode. Jakarta: Departemen Pendidikan dan Kebudayaan Direktorat Jenderal Pendidikan Tinggi Proyek Pengembangan Lembaga Pendidikan Tenaga Kependidikan.

Sagala, Saiful. 2009. Konsep dan Makna Pembelajaran, Bandung: Alfabeta.
Semarayasa, I Ketut. 2010. Pengaruh metode pembelajaran dan Tingkat Motor Educability terhadap keterampilan teknik dasar bermain sepak takraw. Jurnal Pendidikan dan Pengajaran Jilid 43 No $1 \mathrm{Hal}$ 1-88 Singaraja April 2010. ISSN 0215-8250.

Siswandari. 2009. Statistika Computer Based. Surakarta: Sebelas Maret University Press.

Sudjana. 2002. Metode Statistika. Ed. Ke 6. Bandung: Penerbit Tarsito.

Sugiyanto. 1998. Belajar Gerak dan Perkembangan Gerak Manusia BPK. Surakarta: Departemen Pendidikan dan Kebudayaan Republik Indonesia.

Arikunto. 2005. Manajemen Penelitian.ed revisi. Jakarta: Rineka Cipta.

Sukintaka. 2004. Teori Pendidikan Jasmani.Cetakan Pertama. Bandung:Yayasan Nuansa Cendekia.

Sulaiman. 2007. Permainan Sepak Takraw. http://sulaimanfikunnes.blogspot.com/2007/10/se pak-takraw.html [Downloaded 211-2012].

2008. Sepak Takraw: Pedoman Bagi Guru Olahraga, Pembina, Pelatih, dan Atlet. Semarang: UNNES Pres. 